\title{
EXTERNALLY-IMPOSED INSTITUTIONAL BARRIERS ON TRANSNATIONAL ENTREPRENEURS: LESSONS FOR THE IRANIAN-CANADIAN CASE
}

\author{
by \\ Pouyan Tabasinejad \\ BA (Honours), University of Toronto, 2012 \\ MA, University of Toronto, 2013 \\ A Major Research Paper (MRP) \\ presented to Ryerson University \\ in partial fulfillment of the requirements for the degree of \\ Master of Arts \\ in the Program of \\ Immigration and Settlement Studies
}

Toronto, Ontario, Canada, 2016

(C) Pouyan Tabasinejad 2016 


\section{AUTHOR'S DECLARATION FOR ELECTRONIC SUBMISSION OF A MAJOR RESEARCH PAPER (MRP)}

I hereby declare that I am the sole author of this Major Research Paper. This is a true copy of the MRP, including any required final revisions, as accepted by my examiners.

I authorize Ryerson University to lend this MRP to other institutions or individuals for the purpose of scholarly research.

I further authorize Ryerson University to reproduce this MRP by photocopying or by other means, in total or in part, at the request of other institutions or individuals for the purpose of scholarly research.

I understand that my MRP may be made electronically available to the public. 


\title{
EXTERNALLY-IMPOSED INSTITUTIONAL BARRIERS ON TRANSNATIONAL ENTREPRENEURS: LESSONS FOR THE IRANIAN-CANADIAN CASE
}

\author{
Pouyan Tabasinejad \\ Master of Arts 2016 \\ Immigration and Settlement Studies \\ Ryerson University
}

\begin{abstract}
Scholars of transnational entrepreneurship have largely focused on the issue of institutional barriers within the country of origin (COO) context, asserting that transnational entrepreneurs (TEs) can overcome these barriers in a way that constitutes a competitive advantage. What has not been analyzed in the literature is the way in which institutional barriers that are imposed from outside of TE networks can affect TE behaviour and success. In this study, I will introduce the concept of externally imposed institutional barriers, using the example of Iranian TEs as a case study in which to understand this concept. By looking at three cases of Iranian TEs functioning within the context of Iran's exclusion from the global financial system, this study will draw conclusions on the state of Iranian-Canadian TE activity and its implications for scholars, practitioners, and policymakers.
\end{abstract}

Key words: transnational entrepreneurship, institutional barriers, international trade, social capital, Iranian-Canadian, trade policy 


\section{Acknowledgements}

I would like to thank my adviser Professor Horatio Morgan for his crucial guidance and patience throughout the research process and for assuring that the paper strove to meet the highest standards of scholarship. I would also like to thank Professor Harald Bauder for acting as the second reader for this project and for providing valuable insights to improve the paper. I also offer my thanks to my parents for their continued support throughout all of my academic and personal pursuits. 


\section{Table of Contents}

Title Page

Author's Declaration $\quad$ ii

$\begin{array}{ll}\text { Abstract } & \text { iii }\end{array}$

Acknowledgements

Table of Contents $\quad$ v

Introduction $\quad 1$

$\begin{array}{ll}\text { Theoretical Background } & 3\end{array}$

A Social Capital Perspective on TEs 3

An Institutional Perspective on TEs 4

Distinguishing Between COO and Externally Imposed Institutional Barriers 6

$\begin{array}{lr}\text { Context } & 8\end{array}$

$\begin{array}{ll}\text { Socio-Economic Conditions } & 8\end{array}$

A Brief History of Contemporary Canada-Iran Relations 9

Sanctions and their Effect on Iran-Canada Business 11

Banking Restrictions on Iran 12

Previous Research on Iranian TEs in the Context of Sanctions 15

Methods and Methodology 16

$\begin{array}{ll}\text { Illustrative Cases } & 18\end{array}$

AHT - Mohammad-Amin Hajkazemian 18

Gohar Saffron - Mohammad Hossein Khazaei and Hutan Motamedi 20

Saffron Rowhani - Mehrdad Rowhani 21

$\begin{array}{ll}\text { Discussion } & 23\end{array}$

The Effect of Financial Isolation on Iranian TEs 23

Iran's Financial Exclusion as Institutional Barrier for Iranian-Canadian TEs 26

$\begin{array}{ll}\text { Implications } & 30\end{array}$

$\begin{array}{ll}\text { Implications for Theory } & 30\end{array}$ 
Implications for Practitioners

Implications for Policymakers

Limitations and Future Directions

Conclusions

Bibliography 


\section{Introduction}

Over the last 10 years, transnational entrepreneurs (TEs) have received a considerable amount of scholarly attention. In particular, they have been recognized for their enhanced potential to connect and transform their countries of origin (COOs) and countries of destination (CODs) through international business activities. Much of what we know about the international operations and capabilities of TEs is based on the experience of immigrants from East and South Asia (e.g., Saxenian, 2002; Wong, 2004; Upadhya, 2004; Kwak \& Hiebert, 2010). Prior research has emphasized the role of social networks in the observed patterns of internationalization and performance across different groups of TEs (Drori, Honig, \& Wright, 2009). Specifically, a common view is that the social capital (e.g., tacit knowledge about foreign markets) embedded in social networks contributes to the international expansion and success of TEs by helping them overcome social, cultural, and (COO) institutional barriers.

While this social capital theory of transnational entrepreneurship offers important insights, it does not systematically address the presence of formidable externally imposed institutional barriers that TEs might face when attempting to conduct business in some developing countries or regions. By way of example, consider the case of Iranian-Canadian TEs. Until recently, Iran was officially isolated from the global community. In the virtual absence of strong linkages between Iran-based banks and North American banks, existing and aspiring Iranian-Canadian TEs are confronted with an institutional barrier in the form of limited access to a global network of international banks. Whether Iranian-Canadian TEs have strong social ties in Iran does little, if anything, to alleviate their limited access to efficient and low-cost international banking services. 
To complement prior research that emphasizes the role of social capital in the internationalization patterns and success of TEs, I present an institutional perspective in the Iranian-Canadian context. According to this perspective, institutions are "humanly devised constraints that structure human interaction" (North 1990, p.3), or "regulative, normative, and cognitive structures and activities that provide stability and meaning to social behavior" (Scott, 1995, p.33). In short, institutions matter because they shape human behaviour. Focusing on both the formal and informal exclusion of Iran from the international banking system as institutional barrier par excellence, this study will contribute to the literature by looking at how externally imposed institutional barriers might shape the propensity of Iranian-Canadian TEs to conduct international business activities, and the extent of their success. The effect of externally imposed institutional barriers are analyzed in detail through three case studies, developed from information gathered from publically available sources.

The remainder of this paper is organized as follows: an explanation of the theoretical foundation upon which this paper will build its analysis with a view to establish the concept of externally imposed institutional barriers, the context of Iranian-Canadian TE activity; a methodology section; a summary of three illustrative cases of Iranian TEs whose business activities have been adversely impacted by Iran's exclusion from the financial system; a discussion section which analyzes in an exploratory fashion Iranian-Canadian TE activity in the context of the externally imposed institutional barriers represented by Iran's exclusion from the global financial system; and finally, a discussion of the lessons for scholars of transnational entrepreneurship, practitioners, and policy makers. 


\section{Theoretical Background}

\section{A Social Capital Perspective on TEs}

Transnational entrepreneurship is a relatively new field which has only recently begun to attract attention from scholars. It is a subfield of the greater field of immigrant entrepreneurship, a field which has a long history of scholarship, often spurred on by immigrants' historically greater engagement in entrepreneurship. While scholars of immigrant entrepreneurship look at how immigrants establish and maintain entrepreneurial ventures generally, transnational entrepreneurship looks at how immigrants use their transnational orientation and existence to establish and maintain entrepreneurial ventures which straddle multiple countries, usually their COO and their COD (these ventures may also use links with countries where other concerned diaspora communities exist) (Drori et al., 2009; Sequiera et al., 2009). These studies largely focus on why individuals engage in transnational entrepreneurship, the advantages that transnational entrepreneurship offers for those who engage in it, and the patterns that emerge among transnational entrepreneurs. The field is one which is oriented around the individual (or individuals) involved, their existence in multiple socio-cultural, economic, and legal contexts, and the role of social capital in the success of their entrepreneurial activities (Drori et al., 2009; Sequiera et al., 2009).

In an analysis of the competitive advantages of TEs over their non-TE counterparts, Terjesen and Elam (2009) point to the following four sources: a) greater familiarity with multiple cultural settings and an enhanced ability to navigate them, b) an enhanced ability to use their global experiences and capital resources, c) an enhanced ability to use social and professional networks to effectively internationalize their business operations, and d) an enhanced ability to use their transnational experiences, power, and status to internationalize their business 
operations. In line with these themes, Drori et al. ( 2009) describe TEs as having a unique set of tools (due to their transnational existence) that allows them to recognize, develop and effectively exploit business opportunities on the international stage. These tools include "habits, skills, and styles," in addition to ways of thinking, which allow TEs to take advantage of their surroundings effectively (Drori et al., 2009, 1008). Another observation is that TEs tend to have substantial experience and knowledge of varied institutional contexts, including both written and unwritten rules and practices; hence, they are often better positioned than their non-TE counterparts to contract and enforce deals on the basis of social norms when operating in countries with weak legal systems (Drori et al., 2009).

In sum, TEs have an enhanced ability to build and sustain global social networks, and leverage social capital when conducting international business activities. Although these advantages can foster international expansion and success in difficult foreign markets, whether they are a major source of international competitive advantage could depend on the nature of the institutional barriers in question. However, we do not have a clear picture of the kinds of institutional barriers that are particularly difficult to overcome through social ties. By shedding light on this issue, an institutional perspective can offer important insights that complement the extant social capital perspective on TEs.

\section{An Institutional Perspective on TEs}

A useful and oft-cited metaphorical description of institutions comes from economist Douglass North, who described institutions as being "perfectly analogous to the rules of the game in a competitive team sport" (North, 1990, p.4). These institutions are not only the formal "rules of the game," but rather the whole system of written and unwritten rules, norms, and regulations which govern and regulate a community, 
society, or activity (such as a competitive sport); or, as Scott puts it, institutions are the "regulative, normative, and cognitive structures and activities that provide stability and meaning to social behavior" (Scott, 1995, p.33, in Peng et al., 2008, p.922). A crucial aspect of institutions is the system of punishment and coercion which enforces these rules and regulations and assures that the institution survives (North, 1990, p.4). As mentioned above, most scholars of TE look at how institutional barriers can be overcome by TEs in ways that confer competitive advantages.

One of the first studies that focuses on the issue of institutions in the field of transnational entrepreneurship is that of Yeung (2002). Yeung discusses the importance of institutions and the barriers that they can present to TEs by explaining how institutional differences between the COOs and CODs constitute a barrier to all international business activities. Building on this theme, he discusses how TEs use their resources (especially their private knowledge) to overcome these barriers (especially the institutional barriers that exist at the COO side), and even reconfigure institutional arrangements to their advantage (Yeung, 2002). A more recent study by Riddle et al. (2010) similarly focuses on the institutional barriers that exist in the COOs of TEs, and how transnational entrepreneurial activities can overcome these barriers, using the case study of one transnational entrepreneurship incubator (Riddle et al., 2010). Terjesen and Elam (2009) provide a similar treatment to institutional barriers, asserting that TEs are uniquely positioned to negotiate the various rules and regulations (written and unwritten, formal and socio-cultural) that exist in the different countries in which they operate.

To extend the extant institutional perspective on TEs, I will focus on the presence of institutional barriers that are beyond the control of TEs or their contacts, i.e. those which are externally or supranationally imposed on their countries of origin. As discussed above, the 
Iranian-Canadian case provides an interesting contextual setting for exploring this phenomenon. Though scholars of transnational entrepreneurship have not adequately studied the effect of supranational institutional barriers on TE activity, some research in the more general fields of entrepreneurship and business offer some useful insights. For example, Linders et al. (2008) provide a useful framework for understanding how institutional barriers affect international trade. ${ }^{1}$ According to them, institutional barriers are a major impediment to international trade, reducing total international trade by up to five times when compared to what it would be without these barriers (Linders et al., 2008, p.441). Linders et al. identify two types of barriers to international trade - tangible barriers and intangible barriers. Tangible barriers are clearly identifiable in their relation to international trade - these include tariffs, transport barriers, and other types of trade policy. The second type is intangible barriers, which "include incomplete information barriers, cultural barriers and institutional barriers across countries" (Linders et al, 2008, p.444). Linders et al. assert that international trade is especially exposed to institutional barriers, since "international trade involves multiple legal and political systems" (2008, p.444). The institutional barriers addressed here, in the context of Iranian Canadian TE activity, combine elements from both of these types of barriers. As will be shown, there is a complex interplay between tangible government policies and intangible private practices in the observed formidable institutional barriers faced by Iranian-Canadian TEs.

\section{Distinguishing Between Country of Origin and Externally Imposed Institutional Barriers}

Throughout this study, a distinction will be made between those COO side institutional barriers that have been traditionally discussed by scholars of transnational entrepreneurship and 
those institutional barriers that are externally imposed. The COO institutional barriers, as discussed above, refer to the often complex and difficult institutional arrangements that exist in immigrant sending countries with emerging markets. This type of institutional barrier has been analyzed extensively not only by scholars of transnational entrepreneurship, but also by scholars in the field of international business. As Aidis (2005) observes, while emerging economies are not fundamentally different from developed economies, private enterprises in emerging economies have to address state interference, shifting environmental conditions, and corruption to a considerably larger extent than similar enterprises in developed economies (Aidis, 2005). These are the institutional barriers which can possibly be overcome by TEs, whose social capital in their $\mathrm{COO}$ allows them to negotiate new institutional arrangements or gain knowledge that will allow them to circumvent these barriers.

Externally imposed institutional barriers are the type of barrier with which this study is chiefly concerned. It is important to note, once again, that this type of barrier has not been systematically addressed in the literature, and that this study is attempting to provide a theoretical framework through which these types of institutional barriers can be studied. These barriers are termed externally imposed in the present study since they emerge from outside of the networks and reach of TEs. They may be imposed by a supranational institution like a network of state actors in the global financial system (as in the Iranian-Canadian case) or they may be imposed by the COD itself; regardless, the defining characteristic of these barriers is that they are qualitatively different from those barriers that exist at the $\mathrm{COO}$ side. This concept will be analyzed in more depth below.

Following the framework of Linders et al., these barriers can be tangible or intangible, and hamper the international trade that TEs are attempting to facilitate. Whether these 
institutional barriers consist of the trade policies of a COD (such as tariffs or regulatory restrictions on imports), international embargos or sanctions regimes, or a private sector impediment to trade, their defining characteristic is, from the point of view of TEs, that they are resistant to the mobilization of TE social capital. In other words, this type of institutional barrier is outside of the reach of, or external to, the social capital of TEs as traditionally conceived by scholars of the field.

In the section that follows, I will discuss the broader socioeconomic and politicaldiplomatic context within which the emergence of supranational externally imposed institutional barriers has occurred in the Iranian case.

\section{$\underline{\text { Context }}$}

\section{Socio-Economic Conditions}

The Iranian-Canadian community is one which is relatively new to the ethnic mosaic of Canada. Iranians were not one of the groups which entered Canada in the post-WW2 period of intensified immigration (Garousi, 2005). More significant Iranian immigration to the country started in earnest in the 1970's, reaching 600 a year by the year 1978 (Garousi, 2005, p.9). The Iranian Revolution of 1978-9 (and the subsequent Iran-Iraq War of 1980-88) was a turning point for Iranian migration to Canada, and Iranian immigration to Canada grew to several thousand annually in the years after this period (Garousi, 2005, p.9). According to information gathered by the 2001 Census, there were 89,000 Iranian-Canadians in Canada in 2001 (Garousi, 2005, p.9), a number which almost doubled to 163,290 in 2011 according to the National Household Survey (Statcan, 2011). Many of these individuals live in large CMAs, especially Toronto and Vancouver (Garousi, 2005). 
Like many immigrant communities in Canada, this population is more educated than the average Canadian population; 37\% held a university degree or higher compared to average Canadians in 2001 (the latest date for which some educational and employment information is publicly available) (Garousi, 2005, p.17), with educational background focusing on the fields of engineering, mathematics, and computer science, (Garousi, 2005, p.17-18). According to information gathered in 2001, Iranian-Canadians have an average full-time worker income which was comparable to the average Canadian population $(\$ 41,281$ vs $\$ 41,226)$ (Garousi, 2005, p.19). However, Iranian-Canadians had a lower average employment rate (34\% Iranian Canadians did not work as compared to $29 \%$ of all Canadians) and a lower full-time employment rate (28\% of Iranian-Canadians worked full-time in 2001 as compared to 37\% of all Canadians) (Garousi, 2005, p.18). In terms of self-employment, Iranian-Canadians, like other immigrant groups, were more likely to be self-employed than other Canadians; for example, in 2001, Iranian-Canadians in the Toronto CMA were more often self-employed (18\%) than the average population of the CMA (12\%) (Tortabi, 2006, p.54).

\section{A Brief History of Contemporary Canada-Iran Relations}

The institutional barriers that Iranian-Canadian TEs face today are inextricably tied into the history of relations between Iran and Canada, which has largely been determined by Iran's status as a "rogue nation" in the international community generally. The business dynamics between Iran and Canada have been heavily politicized (i.e. dependent on political-diplomatic dynamics) since the beginning of intensive Iranian immigration to Canada in the 1980's and 90's. Relations between Canada and the Islamic Republic of Iran (which came to existence with the Iranian Revolution of 1978/79) have been turbulent from the beginning. Largely due to 
Canadian closeness to the United States in terms of foreign policy (and the former's involvement in the evacuation of six American diplomats during the Iran Hostage Crisis), there were no formal diplomatic relations between Canada and Iran in the years between 1980 and 1990. With the resumption of diplomatic ties in 1990 came a rapidly expanding commercial relationship, and Iran became one of Canada's most important trading partners in the Middle East region (Global Affairs Canada, 2016).

However, this relationship once again began to sour in the 2000's when a series of events, notably the murder of Iranian-Canadian Zahra Kazemi while in Iranian custody, caused considerable strife between the countries (Payton, 2016). In the 2010's, the Canadian government under the Harper administration, arguably as a result of its deep alliance with the pro-sanctions government of Benyamin Netanyahu in Israel (Ahren, 2015), adopted a foreign policy that attempted to isolate Iran politically and economically. In this period, Canada condemned Iran on numerous occasions, adopted an independent sanctions regime and severed diplomatic ties (in 2012), policies which former foreign minister John Baird boasted as constituting "probably the toughest stand in the world on Iran" (Kirkup, 2012). The Harper government passed legislation mandating sanctions that went beyond those obligated by UN security council decisions. This legislation can be divided into two sections; the first was when sanctions were first put in place in 2010 , when certain restrictions were put in place, to the second phase in 2012 when Canada imposed a wide ban on all imports and exports with Iran. Both of these sets of sanctions, especially the second set, went beyond what was mandated by United Nations requirements and even resulted in the closure of the bank accounts of IranianCanadians living in Canada, making it extremely difficult for even small-scale transactions to occur between the two countries (Peritz, 2016). 
With the election of Justin Trudeau's Liberal government, Canada-Iran relations looked to be turning a corner. Re-engagement with the country was one of the Liberal Party's main foreign policy promises and an easing of sanctions on Iran, in accordance with the agreement (Joint Comprehensive Plan of Action or JCPOA) reached between world powers and Iran, occurred on February of 2016 (Global Affairs Canada, 2016). These changes to Canada's laws

lifted the ban on imports from and exports to Iran, except on those materials deemed sensitive because of possible uses for nuclear or ballistic missile technology (some individuals and entities are also covered by the ban) (Global Affairs Canada, 2016). Formal diplomatic engagement has not followed these changes, though the Canadian government has confirmed that talks on reengagement have taken place (Kent, 2016).

\section{Sanctions and their Effect on Iran-Canada Business}

As suggested above, Canadian sanctions on Iran, along with the greater US-led international sanctions regime on Iran, had a deleterious effect on the transnational activities of Iranian-Canadian entrepreneurs seeking to do business with their COO. The reduction of export trade to less than $1 / 10^{\text {th }}$ of what it had been in 1997 ( $\$ 772$ million in 1997 compared to $\$ 67$ million in 2014) two years after the intensified sanctions laws ushered in by the Harper government in 2012 (Global Affairs Canada, 2016) shows the efficacy of these policies in prohibiting business activity. The little trade which remained with Iran centered around foodstuffs (Global Affairs Canada, 2016) (throughout the period of sanctions, Iran-made food products could be found in grocery stores catering to Iranians in Canadian cities like Toronto).

The February 2016 lifting of sanctions in Canada in accordance with the policies of the vast majority of the international community was hoped to reverse this trend and take advantage 
of the economic potential that many observers see in Iran. However, not only in Canada but also the rest of the world, trade with Iran has not expanded as quickly as some might have hoped. Though companies and business groups like the Canadian Chamber of Commerce have expressed considerable interest in doing business with Iran (Canadian Chamber of Commerce, 2016), there does seem to be considerable reticence from some institutions in regards to business with Iran. Banks and other financial institutions have taken a particularly hard line with Iran, erecting major barriers to doing business by refusing to process payments and holding up the flow of capital.

\section{Banking Restrictions on Iran}

Before the JCPOA was signed and implemented in early 2016, Iran was effectively excluded from the global economy. While the direct trade embargo on the country was perhaps most visible feature, a key yet often less understood aspect of the sanctions regime was Iran's exclusion from the global financial system. Through a series of gradual formal and informal processes, Iran saw its banking system being completely shut out of the larger global banking community after stricter sanctions regimes were imposed in 2012 (Erdbrink, 2016). The processes that resulted in an intersection of banks, regulatory agencies, and governments effectively excluding Iran from the global financial system are complex and interwoven and will be analyzed below.

The main aspect of this system of exclusion is the interrelated nature of the modern financial system. Today's major banking groups have operations all over the world. This means that banks are exposed not only to financial risk across different jurisdictions, but also to legal risks across these different jurisdictions. While individual countries' formal sanctions against Iran, like those passed by the Harper government, were important in the latter's inability to do 
business with the concerned countries from a financial perspective, they are no less important than the punitive measures that other countries had in place to support their sanctions regimes. Particularly important were American regulations against Iran.

In the past 7 years, large banking groups from across the world saw themselves strapped with fines in the hundreds of millions, and sometimes billions, for helping Iranian entities (along with those from other sanctioned countries) skirt US sanctions. This included Barclay's (fine of \$298 million in 2010), Standard Chartered (\$227 million in 2012), BNP Parabas (fine of $\$ 8.9$ billion in 2014), HSBC (fine of $\$ 1.3$ billion in 2012), ING (fine of $\$ 619$ million in 2012), Credit Suisse (fine of $\$ 516$ million in 2009), and Lloyds TSB Bank (fine of $\$ 350$ million in 2009) (American Banker, 2014). What these US regulations successfully created in banks was what US official Rachel Loffler called a sense of "shared risk" (Loffler, 2009, p. 102). This effort was so successful that she remarks in 2009: "[b]anks outside the United States often adhere to U.S. watch lists even when they are not required by domestic or international law to do so" (Loffler, 2009, p. 102).

These events meant that banking organizations around the world were unwilling to complete any transactions that were suspected of originating from Iran. In Canada, this extended to even the closing of Iranian-Canadians' bank accounts and the denial of financial services such as mortgages (Peritz, 2016).

Despite the policies of governments around the world and pressure from companies wanting to do business with Iran, banks have been slow to change their policies towards Iran and have even outright resisted Iran's reintegration into the world economy even after the signing of the JCPOA and the lifting of sanctions. A crucial aspect of the deal for Iran was that it would no longer be isolated from the global financial system. However, banks have been so overzealous in 
monitoring and restricting business with Iran that even politicians and world leaders have found it difficult to force them to allow business with Iran.

One example is from the United Kingdom in 2016, when a lubricant firm from David Cameron's own constituency was denied the ability to complete a transaction worth $£ 14,000$ by Barclay's. The (then) Prime Minister rebuked the bank for its actions and demanded that they facilitate trade with Iran. Barclay's response was essentially a rejection of these pleas, pointing to continuing US sanctions on Iran (The Week, 2016). Like Barclay's, other banks often admit that they are not necessarily following the sanctions laws of their own countries, but are rather protecting themselves (and their US operations) from US legislation and fines since that country has kept its sanctions on Iran (The Week, 2016).

Though there have not been similar recorded incidents in Canada, organizations like the Iranian Canadian Congress (an Iranian-Canadian ethnic organization) have reported that they have received complaints from members of the Iranian-Canadian community that they are being denied banking services at the consumer level because of their Iranian nationality (Iranian Canadian Congress, 2016). ${ }^{2}$ The exclusion is a significant barrier continuing to prevent business with Iran, with major banks like Barclay's, HSBC, Standard Chartered, and French bank Societe Generale all stating that they had no plans to resume business with Iran due to US sanctions despite American assurances from officials as highly placed as John Kerry that they would be safe from fines if they allowed business (Reuters, 2016). Furthermore, according to existing US laws, banks are effectively prohibited from completing US dollar transactions (since large transactions of this variety need to go through US banks) (Bauer, 2016).

\footnotetext{
${ }^{2}$ Full disclosure: the author of this paper is on the board of directors of this organization as acting Policy Chair at the time of writing and has been directing the organization's pursuing of the case of treatment of Iranian Canadians by banks
} 


\section{Previous Research on Iranian TEs in the context of Sanctions}

While there is no specific data on the impact of the exclusion of Iran from the global financial system on TEs, there is strong evidence to suggest that it represents an unassailable barrier for Iranian-Canadian TEs. One recent study by Light and Shahlapour (2016) that looked at Iranian TEs in Los Angeles does however provide some insight into how Iranian-Canadian TEs would deal with international institutional barriers. According to the findings in this study, which is the only study I found that specifically focused on Iranian TEs, American sanctions on Iran forced Iranian-American TEs, who worked in the import-export sector to rely more on trade with Iranian diaspora communities (Light and Shahlapour, 2016). Furthermore, informants in their study suggested that some Iranian-American TEs circumvented American sanctions by exporting American goods to China, which then exported them in turn to Iran (Light and Shahlapour, 2016).

This exploratory study shows how TEs from Iranian diaspora communities have considerable difficulties when faced with externally imposed institutional barriers. These barriers hamper business to such an extent that these TEs find themselves forced to avoid trade with their $\mathrm{COO}$, or do so in an indirect and legally risky manner. While their research does present some valuable observations about how externally imposed or COD side institutional barriers can affect TE activity and behaviour, the Iranian-American TEs in Light and Shahlapour's study face the more indirect effects of Iran's exclusion from the international economic system and cannot allow us to fully analyze the effects of this exclusion from the perspective of TEs who do engage in business with Iran. This is why the cases summarized below are valuable to getting the full picture of these externally imposed institutional barriers 
The case studies analyzed below will give an idea of what these barriers mean for Iranian TEs around the world; though these case studies are not based in Canada, they do give an idea of the formidability of these institutional barriers for Iranian-Canadians who want to engage in TE activity between their COO and COD.

\section{Methods and Methodology}

As mentioned above, the main goal of this study is to generate a theoretical foundation for analyzing the existence and role of externally imposed institutional barriers in the context of transnational entrepreneurial activity, using the example of Iranian-Canadian TEs as a case study. In order to accomplish this goal, this paper has drawn upon the published theoretical findings of the academic fields of transnational entrepreneurship, institutional theory, and international business to establish the concept of what is termed externally-imposed institutional barriers. However, what has not been done is to show how TEs on the ground are dealing with these barriers.

Three illustrative cases of Iranian TEs facing externally imposed institutional barriers will therefore be summarized below. To gather the information conveyed in these cases, I drew on news media and the publicly available materials published by these TE firms and their owners. The content includes coverage of the challenges they face, and the strategies and adaptations that they have adopted in response to these challenges, and the costs and risks associated with these strategies. Though these firms do not actually comprise of Iranian TEs operating in Canada, about whom there is a real lack of information in both the literature and news media, they do provide insights that can be applied to the Iranian-Canadian case. Below, I will give a summary of how these firms were chosen. 
The goal of the search for case studies was to find firms owned by Iranian TEs whose challenges in the face of Iran's exclusion from the global financial system were documented. A series of relevant firms were found using the search engines Google and Google News, using key search terms, namely: "Iranian firms," "Iranian exporters," "payment problems," "letters of credit" and "banking problems." The list of firms discovered in this process was then narrowed down to focus on bigger and more established firms that had significant international business activities. This process consisted of three key criteria: that the firm had an English-language website, that the firm had pursued and received international standards certification, and that the firm was oriented towards foreign markets and international trade. Additionally, some firms and individuals had to be eliminated since they were owned by/worked for government entities.

These criteria assured that the firms and individuals being analyzed were legitimate entities which were involved in transnational business or trade. An English-language website indicates that the firm is pursuing international customers. Adherence to international standards indicates that the firm has experience exporting internationally and understands the importance of standards in international trade. Finally, by selecting firms that are focused on international business, I assured that the firms being studied are indeed transnational and are heavily exposed to the exclusion of Iran from the global financial system.

The actual information on these firms was gathered passively. News media, official documents, company and business websites, in addition to video interviews found online, were all consulted to provide vital information about the firms being analyzed. Actual first-hand accounts of how the firms were dealing with Iran's exclusion from the financial system were gathered largely from news media reports which directly interviewed the relevant TEs, though in one case a video interview with the concerned TE posted on YouTube was also consulted. These 
reports allowed me to develop a fairly detailed picture of the concerned firms' respective conditions and strategies in the context of Iran's financial isolation. The value of this information is enhanced by the use of statements and quotations pertaining to these challenges in these news reports. Company and business websites were vital in allowing me to give a detailed background of the firms' activities, including its history, products, export markets, and labour force, though the level of detail on these websites varied according to the firm considered.

\section{Illustrative cases}

\section{AHT - Mohammad-Amin Hajkazemian}

AHT is an established (1963) Iranian firm which manufactures and exports dried nuts and fruits. Its Managing Director is Mohammad-Amin Hajkazemian, who took over his family business in 1999 at the age of 24 . He is the recipient of numerous awards in Iran and is credited by official sources in Iran as being responsible for the modernization and expansion of AHT since he took the helm. AHT has been recognized by the Iranian government as one of the

country's most important non-oil exporters for 8 years in a row (AHT website). The company boasts fully automated factories in line with International Organization for Standardization (ISO) and BRC Global Standards requirements (AHT website). It is Iran's largest exporter of pistachios and dried fruits. It operates 12 factories in Iran (AHT website), employs more than 2000 workers (Breuer, 2015), and offers sophisticated English-language packaging geared towards foreign markets (AHT website).

Speaking on the effect of Iran's exclusion from the financial system on his business in 2012, Hajkazemian remarked that, despite his company's well-established reputation, most of his international transactions were taking place without money transactions. Instead, he was being 
paid in products such as metal cans and cardboard boxes from China, which he imported back to Iran to exchange for cash in the Iranian market, only being able to pay his workers after he sold these bartered goods. With palpable frustration, Mr. Hajkazemian exclaimed to a Reuters reporter that in this situation, "No money is circulating -- it's like thousands of years ago" (Reuters, 2012). Businesses like AHT found themselves unable to obtain letters of credit, a vital component of large international business deals which often require multiple banks to complete a transaction. Hajkazemian explained that he avoided Turkish banks like some of his colleagues were doing, fearful that he may suddenly find his payments frozen, preferring the sureness of barter instead (Reuters, 2012). Speaking three years later at an international food conference (after the nuclear deal was signed) Mr. Hajkazemian indicated that his company was still facing banking restrictions, though he was hopeful that these restrictions would be eased in the future (Breuer, 2015).

In the case of AHT and Mr. Hajkazemian, we see how a large and established transnational firm, with thousands of workers and a history of exporting to multinational partners, is affected by Iran's isolation from the global financial system. Subjected to severe banking restrictions, AHT was unable to make use of financial services that have become accepted practice for firms engaging in international business. As a result of these restrictions, AHT adopted more time-intensive strategies such as bartering to stay in business. These strategies seemingly introduced delays into the firm's operations, suggested by Mr. Hajkazemian's assertion that he would only be able to pay his workers and suppliers after he sold the bartered goods in the Iranian market. Furthermore, Mr. Hajkazemian indicated that he was afraid that incoming payments to his company would be frozen as a result of banking 
restrictions, suggesting that these restrictions generate a significant risk for his firm in terms of receiving payments and staying in business.

\section{Gohar Saffron - Mohammad Hossein Khazaei and Hutan Motamedi}

Gohar Saffron is Iran's largest saffron exporter. Established in 2004, the company has shown a willingness to meet the standards of multiple jurisdictions and has attained numerous certifications, including OHSAS (a British Standard for occupational health and safety management systems), ISO (Organization for Standardization), and FDA certification. In 2010, the company exported $11270 \mathrm{~kg}$ of saffron (a highly sought-after and labour intensive crop which has sold for up to $\$ 2000 / \mathrm{kg}$ on average (Monks, 2015)) (Gohar Saffron website). The majority $(85 \%)$ of this export was to European markets, with expansion to German and Swedish markets coming in 2011 (Gohar Saffron website). In 2007, the company set up a Spain office which was designated as its exclusive franchisee in the country (Gohar Saffron website). The company's Managing Director is Mohammad Hossein Khazaei, and the marketing manager handling Spanish operations is Hutan Motamedi (Gohar Saffron website; Fineren, 2012).

Speaking to Reuters in 2012, Motamedi explained the difficulties of exporting Iranian saffron at a time when Iran was excluded from the world's financial system. They outlined that they were forced to use exchange houses in place of banks, elaborating that "We can do it [export and receive payments] but only with a lot of trouble" (Fineren, 2012). These exchange houses allow business to complete transactions, but have limits on individual transfers and charge higher fees than banks, making them more inconvenient and costly compared to banks. Additionally, Motamedi related how most business does not occur directly between Iran and the market concerned, but rather goes through the Spanish subsidiary, since "it's easier if it [the product] goes via Spain" due to sanctions (Fineren, 2012). 
In the case of Gohar Saffron, we are presented with an internationally oriented and large firm adapting its business strategies to the challenges that the exclusion of Iran from the global financial system presents. In this case, Gohar's adaptive strategy can divided into two parts: the use of exchange houses and moving a large part of its operations to countries, namely Spain. Both of these strategies present certain costs to the firm. Firstly, the use of exchange houses means that large transactions are precluded, and the firm has to rely on smaller transactions to conduct its business. This can present inconveniences, alluded to by the firm's employee Motamedi, which may include difficulty to complete transactions and finding customers willing to do business within these restrictions. Secondly, the transfer of operations to Spain in order to overcome the financial barriers placed on businesses operating out of Iran itself causes the firm to take on costs and risks that it would otherwise not face. This includes the costs of running and operating an office in another country, including visa issues for its workers, the legal risks of doing business in a foreign country, and the increased costs of rent and larger salaries in a developed economy.

\section{Saffron Rowhani - Mehrdad Rowhani}

Saffron Rowhani is a family run saffron exporting business which operates out of the Iranian city of Mashhad in the province of Khorasan (Saffron Rowhani website). Its Managing Director is Mehrdad Rowhani, who established the company in 2009. Its operations are smaller than the other firms covered in this study, exporting about $50 \mathrm{~kg}$ of saffron a month (CNN Money, 2015). The firm has pursued international standards, and is certified by ISO 3632, the ISO's standard system pertaining to saffron grading and purity, according to the company's 
website (Saffron Rowhani website). The firm's main exports markets are in Asia and Europe (Saffron Rowhani website).

Speaking of the effect of Iran's exclusion from the financial system in 2015, Rowhani stated that these restrictions have forced him to change the way his business operates. Firstly, he has had to move away from using banks: "We have to go through private messengers, who are expensive, and deal directly with customers and trust they will pay us. Sometimes they cheat" (Monks, 2015). Furthermore, Rowhani has had to reorient his business operations towards markets in the Gulf region, where the Iranian Rial (the country's currency) is more widely available, to avoid these restrictions (Monks, 2015).

In the case of Mehrdad Rowhani’s Saffron Rowhani, we see how a relatively small and young transnational firm deals with the financial restrictions imposed on Iran. In this case, perhaps because of its smaller size and lack of resources at its disposal as opposed to the other firms studied, the firm has to go through more informal means of receiving payments. Mr. Rowhani mentions the "private messengers" that deal directly with the customer, who may be couriers or other small-scale operations that specialize in these kinds of transactions. The reliability of these messengers is clearly low, since Mr. Rowhani relates that he has been cheated in the past. This adaptation represents a significant risk for this firm, as it exposes the firm to the chance that it will be paid less by the messenger than was agreed upon with the customer, not be paid at all, or that the customer themselves suffers some kind of harm at the hands of these messengers, which increases the likelihood that that customer would not do business with Rowhani's firm in the future. Another adaptation that Rowhani's firm has undertaken is that it changed its target markets to the Gulf region and away from Europe in order to avoid transactions that would expose it to the financial restrictions placed on Iran. This adaption also 
represents a set of costs, since it caused the firm to cut the business ties that it had developed over time in markets where it had previously been active and find new markets.

\section{$\underline{\text { Discussion }}$}

\section{The Effect of Financial Isolation on Iranian TEs}

In this exploratory study, I have sought to shed light on the nature and consequences of externally imposed institutional barriers for TEs, applying some of the lessons learned from the case studies above to those TEs within the Iranian-Canadian community. The cases above show the multiple effects the externally imposed institutional barriers of the financial isolation of Iran have on Iranian TEs around the world. Though the cases studied focus on one type of TE individuals engaged in exporting Iranian foodstuff around the world - they allow us to reach some conclusions about how TEs react when faced with externally imposed institutional barriers. That is to say, we can see how the presence of externally imposed institutional barriers shapes the activities of TEs and what these barriers mean for these TEs' business outcomes. Generally, the effects of these barriers can be divided into three separate yet interrelated aspects: a) the adoption of behaviours and strategies which allow TEs to avoid these barriers, b) the risk and costs associated with the barriers and behaviours and strategies adopted to avoid them, and, most importantly, c) the lack of control that these TEs have to effectively modify or overcome these barriers. In this section, I will analyze each of these aspects with reference to the cases summarized above.

The adoption of behaviours and strategies which allow these Iranian TEs to circumvent or avoid the barriers posed by their COO's isolation from the global financial system is a consistent theme in the cases summarized above. All three of the concerned transnational firms 
have found ways to stay in business in spite of the barriers with which they are faced. In the case of AHT and Mr. Hajkazemian, this amounted to regressing to a barter system that allowed his firm to trade its product for other products that the firm sells in the Iranian market. For Mr. Khazaei and Mr. Motamedi of Gohar Saffron, this consisted of using exchange houses to complete smaller transactions (while incurring fees) and of moving most of their trading operations outside of Iran. For Mr. Rowhani of Saffron Rowhani, this meant changing his target market to an area where the Iranian currency (the Iranian Rial) was more readily available and relying on informal agents whose trustworthiness is questionable at best. The fact that each of these firms adopted a strategy to stay is business is partly a result of the fact that there is a certain survival bias at play in their choosing - i.e. those firms that did not survive Iran's financial isolation could not be studied. However, they do point to an important fact, that the Iranian TEs in question must expend considerable effort in order to maintain the existence of their firms in the face of externally imposed institutional barriers. This will be further discussed below.

Perhaps more important than the fact that the concerned TE firms adapted to the institutional barriers in place is how they did so, and the risks and costs associated not only with the institutional barriers, but more specifically with the various strategies adopted to avoid or circumvent them. All of the concerned cases displayed that their business suffered increased levels of risk and costs as a result of Iran's financial isolation. In the case of AHT, the firm had to expend considerable time, energy, and resources not only to barter with foreign companies for goods that would be sufficiently valuable on the Iranian market, but also to then sell these goods in the Iranian market. Furthermore, the lack of a reliable cash infusion means that the firm has to wait until it has gone through the whole process of bartering and sale on the Iranian market before paying its workers and suppliers. This introduces considerable instability into the firm's 
daily activities, and may force the firm to settle for a less advantageous trade because of time sensitivity, or harm its relationships with its workers and/or suppliers.

In the case of Gohar Saffron, Iran's financial isolation resulted in an inefficient and costly strategy of both relying on inconvenient smaller transactions completed through exchange houses and of moving a large part of the operation outside the country to Spain. The reliance on exchange houses means higher fees and inefficient transactions, increasing the costs of doing business. Moving part of the business outside of Iran increases the costs to the business and increases inefficiency (since most deals have to go through Spain), in addition to opening up the firm to legal issues in a foreign country that may tighten its sanctions laws to match with that of its NATO ally in the United States.

In the case of Saffron Rowhani and Mehrdad Rowhani, Iran's financial isolation forced the firm to undertake considerably risky practices to complete transactions and put its products on the market. By relying on informal agents to complete transactions, Saffron Rowhani opened itself up to fraud, where agents may embezzle funds during transactions or harm the firm's relationships with its customers, in addition to the fact that these agents charge high fees. Furthermore, the firm's relocation of its target market to the Gulf region represented a cost in terms of the ties that it had established in its previous target market.

All three firms were therefore burdened with varying degrees and proportions of risks and costs as a result of Iran's financial isolation. However, perhaps the most important revelation from these cases, which is salient if unspoken, is the fact that none of these TEs showed an ability to negotiate with or effectively overcome these barriers without undertaking significant costs and risk. This is in direct contradiction to how TEs have been conceived by scholars of transnational entrepreneurship. Instead of being able to alter the institutional arrangements which 
have erected the relevant barriers or overcome the barriers in a way that proves a competitive advantage, we instead see TEs who seem to be desperately holding on in extremely difficult circumstances. The isolation of Iran from the global financial system is a barrier which is outside of the reach of the social capital of the TEs in question - their networks and private knowledge cannot allow them to overcome or negotiate with the institutions who are erecting these barriers. As a result, all of the firms analyzed merely adopted whatever strategies they could, despite their costs and risks, to assure the survival of their business in circumstances that severely constrain their growth and endanger their long-term existence.

\section{Iran's Financial Exclusion as Institutional Barrier for Iranian-Canadian TEs}

As noted above, institutional barriers as conceived by conventional scholarship in the field of transnational entrepreneurship have assumed that TEs can overcome them through their social capital and other resources, and even that institutional barriers present opportunities for TEs - since it means that they can access resources and markets that are unavailable to other entities. However, what we have in the Iranian case is an instance where institutional barriers are externally imposed. As shown above, Iranian TEs cannot use their social resources in their COO to overcome these barriers - for example, there is no local politician or official that Iranian TEs can access to affect a favourable institutional arrangement or from whom to gain advantageous information that will allow them to circumvent the barriers presented by Iran's financial isolation. Instead, the institutional barrier in question is imposed by an external and powerful outside force - i.e. a network of powerful state and private actors in the international banking system. 
Using the framework provided by Linders et al. (2008), we can categorize the exclusion of Iran from the global financial system as a combination of tangible and intangible barriers, making the business activities of TEs extremely difficult. The tangible aspect of the barrier is that this exclusion is the result of a policy imposed by the US government, while the intangible aspect is the often opaque practices of the banks that are carrying out this exclusion on the ground. As observed by Linders et al., the nature of international trade is such that it requires coordination between various state and private actors. In this case, the state actors, i.e. the US government, are, through the real or perceived threat of heavy fines, influencing private actors in the global financial system so that trade between Canada and Iran is rendered exceedingly costly, if not effectively impossible.

This particular institutional barrier presents an extremely formidable challenge and limitation to Iranian-Canadian TEs. If banks in Canada are unwilling to complete transactions originating, or even suspected of originating, in Iran, then the entrepreneurs who depend on business between the two countries can find themselves unable to receive payments for shipments and services. If they decide to go the path of Gohar Saffron and use exchange houses, they may find themselves paying high fees which a nascent business cannot sustain. Engaging in bartering seems at first glance unlikely for Iranian-Canadian entrepreneurs because of the distance between the two countries. Additionally, relying on informal methods for payment may be inappropriate as a strategy in a country like Canada, where the bank system is established and widely used by businesspeople - though it is possible that informal money exchange networks like hawala could be used by some TEs.

Furthermore, there is the possibility that Iranian-Canadian TEs who do find a financially sustainable way to engage in trade with Iran may still be putting themselves at risk legally. As a 
result of the fact that many countries, including Canada, continue to have sanctions on certain Iranian entities, there is a risk that companies who are doing business with Iran will be conducting business with sanctioned entities without knowing that they are doing so. Sanctioned entities such as the Islamic Revolutionary Guard Corps are known to indirectly own many businesses in Iran, and a TE may not know that they are doing business with a sanctioned entity until it is too late. This reality is another way that institutional barriers affect Iranian-Canadian TE activity. Though this is not a direct result of Iran's exclusion from the financial system, it is part of the same set of institutional barriers that Iranian-Canadian TEs must deal with when attempting to engage in business.

These realities can severely impact the TEs' ability to grow their business, obtain loans from personal or formal sources, and gain customers. These barriers also significantly increase the risks that Iranian-Canadian run if they do manage to engage in business with Iran, putting their businesses in a precarious position and undermining their long-term sustainability. As shown in the case studies analyzed above, doing business with Iran in the context of these externally imposed institutional barriers is extremely difficult. The case studies show that business with Iran in this context requires the adoption of a variety of costly strategies that may still risk the financial sustainability of a TE's business. The institutional and social resources that Iranian-Canadian TEs possess cannot be leveraged effectively to change the complex interactions which have resulted in the global financial system's exclusion of Iran. No matter how well-placed Iranian-Canadian TEs are in terms of connections in their COO, and no matter how much they benefit from private information, they cannot convince the international banking system more effectively than when American Secretary of State John Kerry or British Prime Minister David Cameron attempted to do the same. 


\section{The Future of Iranian-Canadian Transnational Entrepreneurship}

An important question is what the existence of these barriers mean for the development of Iranian-Canadian TE activity generally. The above suggests that, in the current context where Iran's financial isolation is a fact of life, Iranian-Canadian TEs and aspiring TEs would be faced with considerable cost and risk if they engaged in business with Iran. Whether Iranian-Canadian TEs would engage in business despite these costs and risks depends on the profile of these TEs. Unlike the firms analyzed in the case studies above, aspiring Iranian-Canadian TEs who are considering engaging in business between Iran and Canada may find that it is not worthwhile, either solely because of the costs and risks involved or because they also have safer and more reliable options in the paid employment sector. Other Iranian-Canadian TEs with older and more established businesses may find themselves too deeply invested to cease operations due to the costs and risks, adopting a similar orientation as the cases analyzed above.

Aspiring Iranian-Canadian TEs who do go through with business with Iran may find that their nascent firms have a low chance of survival and growth due to the barriers in place and the strategies they have to adopt in order to avoid or circumvent these barriers. Finally, any TE doing business with Iran may find themselves legally liable for unknowingly engaging in business with sanctioned entities, creating the possibility for frozen assets or payments, fines, civil suits, or even imprisonment. Therefore, it is likely that Iranian-Canadian transnational entrepreneurship as a form of business activity is and will continue to be severely restricted by the externally imposed institutional barriers represented by Iran's exclusion from the global financial system. 


\section{$\underline{\text { Implications }}$}

The case of Iranian-Canadian TEs above shows that the social capital of TEs is not enough to overcome every barrier. In this case, we saw how institutional barriers imposed by an external source (termed in this study as externally imposed institutional barriers) can severely limit the activities of TEs without much space for recourse. This observation has considerable implications for the field of transnational entrepreneurship. While, as mentioned above, scholars of the field have created a conception of TEs as consistently able to overcome and even benefit from institutional barriers by virtue of their social capital (networks and knowledge), the reality is much more complex. There exist externally imposed institutional barriers that are unlikely to be overcome or changed by TEs. The example of Iranian TEs is an extreme case, but it shows how externally imposed institutional barriers can influence TE behaviour and success. This observation is not only relevant to the theoretical understandings of transnational entrepreneurship, but also has implications for practitioners of transnational entrepreneurship and for policymakers who are interested in encouraging transnational entrepreneurship.

\section{Implications for Theory}

As mentioned above, externally imposed institutional barriers constitute a veritable theoretical blind spot for scholars of the field of transnational entrepreneurship. The assumption behind the literature on the issue of institutional barriers on TEs is that the relevant barriers with which TEs are faced exist on the COO side. Specifically, there is an assumption that developing or emerging economies do not have adequate institutional infrastructure to allow the free flow of goods and services. In this scenario, TEs step in and use their social capital, along with the private knowledge that capital affords them, to establish ventures, essentially gaining a 
competitive advantage by overcoming institutional barriers which prove unassailable to other business entities. However, the assumption that institutional barriers predominantly exist on the COO side does not hold in some settings; specifically, extremely formidable institutional barriers can also exist on the COD side or even supranationally. In the Iranian and Iranian-Canadian example, we see how a group of TEs are subjected to a series of institutional barriers over which they have no influence and in regards to which their social capital is largely ineffective. In this case, the institutional barriers exist at the COD side rather than at the $\mathrm{COO}$, with institutions in the COD (banks) erecting barriers to TE activity.

These issues suggest that the extant social capital theory of transnational entrepreneurship can be advanced by a broader conceptualization of institutional barriers and their relationship to TEs. While institutional barriers at the $\mathrm{COO}$ side, where TEs may have considerable social capital (i.e. influence and knowledge), can indeed prove to be surmountable and even a longterm advantage (where TEs have a competitive advantage over other entities), I have shown that these are not the only type of institutional barrier relevant to all TEs. Institutional barriers in the COD and supranational barriers are something with which TEs also have to contend, and they may often find themselves unable to overcome or negotiate with these barriers. To TEs, these are externally imposed barriers erected by entities over which and within TEs have very little influence or social ties. When faced with these barriers, TEs may have very little recourse. Though often better established in their CODs and of a higher socio-economic background than either the general immigrant population or regular ethnic entrepreneurs, TEs may find it very difficult to influence COD institutions. Furthermore, as in the Iranian-Canadian example, these institutional barriers may have a supranational nature, and so are resistant even to (likely limited) resources that TEs could exert at the COD level. 
When looking at a TE population, scholars of transnational entrepreneurship might find it helpful to carefully consider whether that population is subject to institutional barriers over which it has little influence. Not all TEs will have clear externally imposed institutional barriers with which to contend as in the case of Iranian-Canadian TEs, and scholars will need to be vigilant in uncovering the institutional barriers at play in the activities of TEs. These institutional barriers may exist across multiple jurisdictions and be imposed by political, regulatory, or private entities, or a combination thereof. These barriers may influence TE activity in an obvious and prohibitive way, as in the Iranian-Canadian case, or they may have more subtle influences upon TE behaviours and outcomes: increasing risk, making access to credit and financing more difficult, and inhibiting growth.

Recent world events have also made it more likely that TE communities from around the world will see themselves faced with daunting externally imposed institutional barriers in coming years. As former US official Rachel Loffler (2009) asserts, the global financial system is increasingly becoming integrated into the foreign policy of influential nations, particular the US itself. As this integration gains pace, we will continue to see more TE communities affected by sanctions regimes. In the past decade, sanctions have been imposed on countries such as Burma (Myanmar), Russia, Guatemala, and Iran itself (Hose \& Genser, 2007; US Treasury, 2016). This is in addition to smaller scale or retaliatory sanctions by countries such as Russia and Brazil against the US, the EU, Canada, and other Western countries (Stanglin, 2010; BBC, 2014). As financial isolation increasingly becomes part of and even replaces traditional international conflict, scholars of transnational entrepreneurship will need to be prepared to appropriately analyze and recognize the realities with which the TEs active within these affected countries are faced. 


\section{Implications for Practitioners}

The above analysis showed how TEs face externally imposed institutional barriers that can limit their business activity and success. While this phenomenon has direct implications for theorists of the field of transnational entrepreneurship that have been analyzed, an equally important set of implications exist for TEs, the practitioners of transnational entrepreneurship. The characteristic of the institutional barriers analyzed above which most limits TEs from overcoming or rearranging the barriers is that they are imposed from outside of the TEs' social networks. In other words, TEs faced with externally imposed institutional barriers cannot overcome them in the same way which scholars of transnational entrepreneurship have observed with barriers that exist on the $\mathrm{COO}$ side. Unlike in the $\mathrm{COO}$, the institutions in the COD, as well as supranational institutions, are not easily accessible to TEs. Therefore, it is important to explore the strategies TEs can adopt when faced with such challenges.

Depending on the nature of the institutions that are erecting barriers, the TEs may have to adopt differing specific strategies. Regardless of the institutions, however, TEs have to increase their institutional influence at the COD side. This may mean establishing ethnic based business associations through which they can collectively exert influence on the institutions in question (as an example, in the case study examined there exists no active Iranian-Canadian business association that could lobby the Canadian government or banks); establishing ties with the institutions in question; attempt to establish methods to influence politicians in the COD; consult with legal/institutional experts to determine their options in terms of the concerned institutional barriers, among others. The main vulnerability for TEs in terms of COD or externally imposed institutional barriers lies in the fact that TEs, like other immigrant/ethnic entrepreneurs are generally not well-established in the COD, lacking the resources (such as networks, language, 
political influence, and cultural familiarity) that allow them to overcome institutional barriers at the COO. Clearly, despite the suggestions made above, TEs have limited options in terms of increasing these resources; policymakers therefore have a strong role to play in advocating on behalf of TEs facing these issues.

\section{Implications for Policymakers}

Policymakers in CODs like Canada have a vested interest in encouraging TE activity between their countries and immigrants' COOs that firms often have difficulty entering. Though not much research has been done on the subject, recent statistical analysis has shown that immigrant settlement in CODs tends to correlate strongly with trade with the COOs of those immigrants, likely facilitated by TEs (Sui \& Morgan, 2014; Sui, Morgan, \& Baum, 2015; White, 2010). In order for policymakers to encourage this trade, they need to assure that the TEs in question are as unburdened as possible by institutional barriers. This means that policymakers will need to establish methods of consulting with TEs from various communities, keeping abreast of their difficulties and challenges in regards to institutional barriers they face. Policymakers can then either enact policies which will address these institutional barriers or negotiate with the concerned institutions to dismantle or ease these barriers.

In the case of Iranian-Canadian TEs, the government of Canada can address the institutional barriers which these TEs face through a mix of legislation and negotiation with banks who have operations in Canada. Canadian laws could be changed to allow for more leeway for businesses who want to trade with Iran, reducing their liability if they unknowingly do business with sanctioned entities, providing they prove adequate due diligence; in this way, risks on the Canadian side could be reduced and banks may be more willing to do business with 
Iran. Furthermore, Canada could lobby the American government, in concert with other countries who wish to facilitate trade with Iran, to clarify and loosen the restrictions that banks face when doing business with Iran.

\section{$\underline{\text { Limitations and Future Directions }}$}

This study was largely exploratory and therefore has numerous limitations that could be overcome by future studies. One important limitation of this paper is that the subjects who were analyzed were not actually prospective and or current Iranian-Canadian TEs. Instead, they were TEs who were operating between Iran and various countries. While the analysis of these subjects did provide some useful insights about the challenges facing Iranian TEs around the globe, future studies could focus on Iranian-Canadian entrepreneurs who are engaged in business with Iran to get a full picture of what is actually happening in Canada. Another limitation of this work is that the passive collection of information through internet resources could not give a full profile of the TEs in question, creating a bias in favour of choosing TE firms that were large and still in business despite the sanctions regime and Iran's isolation. Future studies could engage in collecting primary data, distributing surveys, and conducting interviews that can illuminate questions about both TEs and aspiring or former TEs, including their education, socioeconomic background, and length of residence outside of Iran, giving a fuller picture of the TEs in question.

Ideally, this study would have been able to clinically identify and profile IranianCanadian TEs in Canada through a survey. By doing so, this research could definitively answer important questions which were not addressed in this paper, such as whether the intensity of ties 
that TEs had in Iran would influence their willingness or their perception of their ability to do business in Iran.

Future studies also may address the effect of externally imposed institutional barriers on Iranian-Canadians in a more intimate fashion. Through a combination of surveys and in-depth interviews with Iranian-Canadian TEs who presently do, or have attempted to do, business with Iran, these studies could better quantify how Iran's financial isolation is impacting this group. This type of study could provide definitive proof of the effect that this barrier has on this community of TEs in Canada itself and the specific strategies that TEs in this country are adopting.

\section{Conclusions}

This study has developed the concept of externally imposed institutional barriers for TEs, taking the example of Iran's financial isolation as a case study. After developing the concept of externally imposed institutional barriers, this theory was applied to Iranian TEs through an analysis of three separate cases. This analysis showed that TEs attempting to do business between Iran and other countries found themselves faced with considerable challenges as a result of Iran's financial isolation. The analysis showed that these TEs undertook numerous risky and costly behaviours to avoid these institutional barriers, but could not overcome them in the way that scholars of transnational entrepreneurship have posited. Instead, the TEs in question were faced with an institutional barrier which has not been studied by scholars of the discipline barriers that are outside of the reach of the social capital of TEs. Once this phenomenon was firmly established, I then discussed what the existence of these barriers meant for the future of Iranian-Canadian transnational entrepreneurship, coming to the conclusion that these barriers 
likely have a heavily restrictive effect on the TE activity of this community. I then ended with the implications of this research for scholarship, practitioners, and policymakers.

The most important lesson from this study is that, though TEs are - like other entrepreneurs - highly adaptive and creative, they are also exceedingly vulnerable to barriers that exist at the international level. Neither policymakers or scholars of the field should overlook the fact that TE activity, like all international trade, involves a large number of private and state institutions, institutions like the global financial system, which are often outside of the reach of even the best placed TE. Policymakers must take into account the importance of TE activity to their country's international trade and adopt appropriate policies to encourage such activity by working to dismantle these externally imposed institutional barriers. Scholars must also take into account the fact that TEs are not the barrier-busters that they have been conceived as in the literature, and illuminate the institutional barriers that TEs cannot overcome. This is especially important in an age when externally imposed institutional barriers such as sanctions and exclusion from the global financial system are becoming more common and tied in with the foreign policy of influential nations. 


\section{Bibliography}

Ahren, R. (2015, October 19). In Canada election, support for Israel not up for discussion. Retrieved August 25, 2016, from http://www.timesofisrael.com/in-canada-election-support-forisrael-is-not-up-for-discussion/

AHT. (n.d.). About Us. Retrieved August 25, 2016, from http://retail.ahtfoods.com/AboutUs.aspx

Aidis, R. (2005). Institutional barriers to small-and medium-sized enterprise operations in transition countries. Small business economics, 25(4), 305-317.

American Banker. (2014). The Seven Largest Sanctions-Related Fines Against Banks. Retrieved August 25, 2016, from http://www.americanbanker.com/gallery/the-seven-largest-sanctionsrelated-fines-against-banks-1068360-1.html

Bauer, K. (2016, April 5). Potential U.S. Clarification of Financial Sanctions Regulations. Retrieved August 25, 2016, from http://www.washingtoninstitute.org/policyanalysis/view/potential-u.s.-clarification-of-financial-sanctions-regulations

BBC. (2014, August 7). Russia hits West with food import ban in sanctions row. Retrieved August 25, 2016, from http://www.bbc.com/news/world-europe-28687172

Breuer, A.. (2015, October 11). FruitWorldMedia at ANUGA - presenting AHT [Video file]. Retrieved from http://www.youtube.com/watch?v=6nyGCbxD848

Canadian Chamber of Commerce. (2016, February 5). The Canadian Chamber of Commerce Welcomes Re-establishment of Economic Ties with Iran. Retrieved August 25, 2016, from http://www.chamber.ca/media/news-releases/160205-canadian-chamber-welcomesreestablishment-of-economic-ties-with-iran/

Drori, I., Honig, B., \& Wright, M. (2009). Transnational entrepreneurship: An emergent field of study. Entrepreneurship Theory and Practice, 33(5), 1001-1022.

Erdbrink, T. (2016, January 28). Iranian Oil Shipper Hopes to Make Up for Lost Time as Sanctions End. Retrieved August 25, 2016, from http://www.nytimes.com/2016/01/29/world/middleeast/iran-sanctions-oil-shipping.html

Fineren, D. (2012, February 29). Barter, other steps help Iran firms beat sanctions. Retrieved August 25, 2016, from http://www.reuters.com/article/us-iran-trade-idUSTRE81S12G20120229

Garousi, V. (2005). Iranians in Canada: A statistical analysis. In Proceedings of the 3rd Scientific Seminar on the Discourse of Overseas Iranian Youth, Tehran, Iran.

Global Affairs Canada. (2016, February 5). Canada amends its sanctions against Iran. Retrieved August 25, 2016, from http://www.international.gc.ca/media/aff/newscommuniques/2016/02/05a.aspx?lang=eng 
Global Affairs Canada. (2016, February 5). Canadian Sanctions Related to Iran. Retrieved August 25, 2016, from http://www.international.gc.ca/sanctions/countries-

pays/iran.aspx?lang=eng

Henn, S. (2013). Transnational entrepreneurs and the emergence of clusters in peripheral regions. The case of the diamond cutting cluster in Gujarat (India). European Planning Studies, 21(11), 1779-1795.

Hose, R. L., \& Genser, J. M. (2007). Are EU trade sanctions on Burma compatible with WTO law. Mich. J. Int'l L., 29, 165.

Iranian Canadian Congress. (2016, July 12). ICC Policy Priorities. Retrieved August 25, 2016, from http://www.iccongress.ca/policy_priorities_iranian_canadian_congress

Kent, M. (2016, June 10). Canada has started 'official' talks with Iran to renew ties, says Stéphane Dion. Retrieved August 25, 2016, from http://www.cbc.ca/news/politics/canada-irantalks-stephane-dion-1.3630446

Kirkup, K. (2012, September 26). Baird hammers Iran for Canadian travel warning. Retrieved August 25, 2016, from http://www.torontosun.com/2012/09/26/baird-hammers-iran-forcanadian-travel-warning

Kwak, M. J., \& Hiebert, D. (2010). Globalizing Canadian education from below: A case study of transnational immigrant entrepreneurship between Seoul, Korea and Vancouver Canada. Journal of International Migration and Integration/Revue de l'integration et de la migration internationale, 11(2), 131-153.

Light, I., \& Shahlapour, P. (2016). Transnational Iranian entrepreneurs in the import/export industry of Los Angeles. International Journal of Business and Globalisation, 16(3), 304-313.

Linders, G. J. M., Burger, M. J., \& Van Oort, F. G. (2008). A rather empty world: the many faces of distance and the persistent resistance to international trade. Cambridge Journal of Regions, Economy and Society, 1(3), 439-458

Loeffler, R. L. (2009). Bank shots: how the financial system can isolate rogues. Foreign Affairs, 101-110.

Monks, K. (2015, June 8). Iran's home grown treasure: The spice that costs more than gold. Retrieved August 25, 2016, from http://money.cnn.com/2015/06/08/news/iran-saffron-red-gold/

North, D. (1990). Institution, Institutional Change and Economic Performance. Cambridge: Cambridge University Press.

Payton, L. (2012, September 21). Canada closes embassy in Iran, expels Iranian diplomats. Retrieved August 25, 2016, from http://www.cbc.ca/news/politics/canada-closes-embassy-iniran-expels-iranian-diplomats-1.1166509 
Peng, M. W., Wang, D. Y., \& Jiang, Y. (2008). An institution-based view of international business strategy: A focus on emerging economies. Journal of international business studies, 39(5), 920-936.

Peritz, I. (2016, January 27). Iranian-Canadians 'squeezed' by sanctions hopeful about policy change. Retrieved August 25, 2016, from http://www.theglobeandmail.com/news/national/iranian-canadians-squeezed-by-sanctionshopeful-about-policy-change/article28425044/

Reuters. (2016, May 12). Kerry seeks to soothe European bank nerves over Iran trade. Retrieved August 25, 2016, from http://www.reuters.com/article/us-iran-banks-kerry-idUSKCN0Y30OJ

Ribeiro, A., Rezaei, S., \& Dana, L. P. (2012).Gender and family in transnational entrepreneurship. International Journal of Business and Globalisation, 8(3), 409-420.

Riddle, L., Hrivnak, G. A., \& Nielsen, T. M. (2010). Transnational diaspora entrepreneurship in emerging markets: Bridging institutional divides. Journal of International Management, 16(4), 398-411.

Saffron Rowhani. (n.d.). About Us - Iranian Saffron supplier and exporter. Retrieved August 25, 2016, from http://www.rowhanisaffron.com/about-us-2/

Saxenian, A. (2002). Transnational communities and the evolution of global production networks: the cases of Taiwan, China and India. Industry and Innovation, 9(3), 183-202.

Scott, W. R. (1995). Institutions and organizations. Thousand Oaks, CA: Sage.

Sequeira, J. M., Carr, J. C., \& Rasheed, A. A. (2009). Transnational entrepreneurship: determinants of firm type and owner attributions of success. Entrepreneurship Theory and Practice, 33(5), 1023-1044.

Stanglin, D. (2010, March 09). Brazil slaps trade sanctions on U.S. to retaliate for subsidies to cotton farmers. Retrieved August 25, 2016, from http://content.usatoday.com/communities/ondeadline/post/2010/03/brazil-slaps-trade-sanctionson-us--to-retaliate-for-subsidies-to-cotton-farmers/1

Statcan. (2016). 2011 National Household Survey: Data tables. Retrieved August 25, 2016, from http://www12.statcan.gc.ca/nhs-enm/2011/dp-pd/dt-td/Rp-eng.cfm?LANG=E

Sui, S., \& Morgan, H. (2014). Selling beyond the U.S.: Do recent immigrants advance Canada's export agenda? The Conference Board of Canada.

Sui, S., Morgan, H. M., \& Baum, M. (2015). Internationalization of immigrant-owned SMEs: The role of language. Journal of World Business, 50(4), 804-814.

Terjesen, S., \& Elam, A. (2009). Transnational entrepreneurs' venture internationalization strategies: A practice theory approach. Entrepreneurship Theory and Practice, 33(5), 1093-1120. 
Torbati, M. (2006). Immigrant entrepreneurship: A case study of Iranian businesses in the Toronto CMA. Proquest.

Upadhya, C. (2004). A new transnational capitalist class? Capital flows, business networks and entrepreneurs in the Indian software industry. Economic and Political Weekly, 5141-5151.

U.S. Department of the Treasury. (2016). Sanctions Programs and Country Information. Retrieved August 25, 2016, from https://www.treasury.gov/resourcecenter/sanctions/Programs/Pages/Programs.aspx

The Week. (2016, March 14). Cameron steps in after Barclays blocks trade deals with Iran. Retrieved August 25, 2016, from http://www.theweek.co.uk/70542/cameron-steps-in-afterbarclays-blocks-trade-deals-with-iran

Wong, L. L. (2004). Taiwanese immigrant entrepreneurs in Canada and transnational social space. International migration, 42(2), 113-152.

Yeung, H. W. C. (2002). Entrepreneurship in international business: An institutional perspective. Asia Pacific Journal of Management, 19(1), 29-61. 